\title{
STRATEGIC ACTION FIELDS AND THE CONTEXT OF POLITICAL ENTREPRENEURSHIP: HOW DISABILITY RIGHTS BECAME PART OF THE POLICY AGENDA
}

\author{
David Pettinicchio
}

\begin{abstract}
In the late 1960s and early 1970s, disability rights found a place on the U.S. policy agenda. However, it did not do so because social movement groups pressured political elites or because politicians were responding to changes in public preferences. Drawing from recent work in neoinstitutionalism and social movements, namely the theory of strategic action fields, I posit that exogenous shocks in the 1960 s caused a disability policy monopoly to collapse giving way to a new policy community. Using original longitudinal data on congressional committees, hearings, bills, and laws, as well as data from the Policy Agendas Project, I demonstrate the ways in which entrepreneurs pursued a new policy image of rights within a context of increasing committee
\end{abstract}

Research in Social Movements, Conflicts and Change, Volume 36, 79-106 Copyright $(C) 2013$ by Emerald Group Publishing Limited

All rights of reproduction in any form reserved

ISSN: 0163-786X/doi:10.1108/S0163-786X(2013)0000036006 
involvement, issue complexity, and space on the policy agenda, and the consequences this had on policy.

Keywords: Strategic action fields; political entrepreneurs; institutional activism; policy communities; disability rights; agenda setting

\section{INTRODUCTION}

Scholars have increasingly characterized social movements as "everyday politics" (Goldstone, 2003; Meyer \& Minkoff, 2004). As activism inside and outside of institutions becomes blurred (see Pettinicchio, 2012), once separate fields of actors increasingly overlap. Movement activists come to interact frequently with political elites through ties that are forged between interest groups and social movement organizations (SMOs), congressional committees, and agencies of the executive branch. This in turn creates a community of actors, including political entrepreneurs, interested in promoting a common cause - that is, a strategic action field (SAF).

I use entrepreneurship to refer to proactive behavior on the part of political elites (i.e., socially skilled actors with access to institutional resources and influence) such that their actions "change the direction or flow of politics" (Schneider \& Teske, 1992, p. 737). As SAFs, policy communities are the contexts within which political entrepreneurship and institutional activism take place. Policy communities are characterized by the overlap of preexisting fields including governmental, nonprofit, corporate, and grassroots. It is therefore critical to shed light on the relationship between political entrepreneurs and the contexts that facilitate their behavior.

Related literatures have sought to address the institutional context of social change (see Lawrence \& Suddaby, 2006 on institutional work; Miller \& Demir, 2007a on policy communities; Baumgartner \& Jones, 1993 and Jones \& Baumgartner, 2005 on agenda setting; King, 1997 and Baughman, 2006 on committee structures and committee interactions). This body of work suggests a fairly loose, but organized, field of actors that extend beyond the elected branch of government to include actors in the executive branch as well actors outside the government. Recently in sociology, specifically the study of organizations and social movements, a theory of strategic action fields (SAFs) has been proposed (see Fligstein \& McAdam, 2011, 2012) which builds on and brings together existing work in institutional theory (or neo-institutionalism), political and organizational sociology, and social 
movements (e.g., McCarthy \& Zald's (1977) social movement industry and social movement sector; DiMaggio \& Powell's (1983) organizational fields; Roa, Morill, \& Zald's (2000) interstices; Stearns \& Almeida's (2004) state actor-social movement coalitions; McCarthy's (2005) Velcro triangles).

In this chapter, I discuss the nature of policy communities as SAFs so as to describe the context within which political entrepreneurs (aka, strategic actors) work to promote a particular policy image, which eventually leads to important policy change. I use the case of disability to illustrate the rise of a policy community whereby rights discourse was allowed to flourish. I explain the ways in which a policy monopoly composed of incumbent and state-legitimated disability groups, rehabilitation, health and social welfare professionals, and key political elites within a small number of congressional committees and subcommittees gave way to a broader policy community of multiple players across a variety of policy domains. It was within this new field of actors whereby a rights policy framework emerged. I use original longitudinal data based on content analysis of the Congressional Record/ LexisNexis Congressional as well as data from the Policy Agendas Project to describe how a reconfiguration of fields facilitated political entrepreneurship. I discuss the implications of linking policy communities to SAFs, particularly the ways in which this sheds light on the dynamic interplay between insiders and outsiders in producing policy change.

\section{STRATEGIC ACTORS IN STRATEGIC ACTION FIELDS}

SAFs are a "meso-level social order where actors (who can be individual or collective) interact with knowledge of one another under a set of common understandings about the purposes of the field, the relationships in the field (including who has power and why), and the field's rules" (Fligstein \& McAdam, 2011, p. 3). SAFs draw attention to the ways in which actors within organizations intersect with other actors in other organizations, thereby creating a field or context which helps to shed light on the reproduction of social order as well as the production of social change. Since strategic action requires strategic actors, a theory of fields requires a specification of the link between micro (i.e., strategic actors) and macro (i.e., the context that enables entrepreneurial behavior).

Fligstein and McAdam (2012) outline four key features of SAFs. First, actors share a common understanding of their roles in terms of the purpose 
of the field. That is, SAFs coalesce through purposive goal-oriented behavior on the part of entrepreneurs. Second, actors hold different positions in a field such that some actors have more power or are seen as more legitimate than other actors (see also Gamson, 1975 on incumbent and challenging groups). This is relevant to policy communities and entrepreneurship because it determines the extent to which political entrepreneurs are able to exert their influence so as to reframe political discourse and policy images.

Third, actors agree on the rules that govern their interaction. Presumably, these rules can be both formal and informal. For instance, formal institutional rules govern the political field, yet less formal rules also exist about the interaction between parties and congressional committees, and between the elected branch and the executive branch (see Weingast 2005). And fourth, actors tend to view their role and others' role from the perspective of their position in the field. This implies that actors may come into a field with different, perhaps conflicting, ways of understanding goals and objectives of the policy community. A major role of socially skilled actors, such as political entrepreneurs, is to bring other actors in line with their framing of an issue. Entrepreneurs are constantly looking for opportunities, often brought on by broader institutional changes, to improve their place in a field and to ensure that their framing of the issue rules out the competition.

While actors are embedded within SAFs, SAFs are themselves embedded within broader environments. Policy communities, by their very nature, are embedded within political alliances and relationships that shape fields. This begs the question as to how SAFs come into being. Although Fligstein and McAdam's (2012, p. 20) theory of fields accounts for both exogenous and endogenous sources of change, they emphasize the role of exogenous shocks or events in shaping the emergence of SAFs. Exogenous shocks create new intersections of players and thus new normative contexts surrounding interaction. ${ }^{1}$ The social disorganization that occurs as a result of exogenous shocks creates an opportunity for entrepreneurship. Changes in party control, broad policy moods, and committee composition beginning in the 1960s dismantled existing arrangements and allowed for a new disability policy community to emerge, as well as entrepreneurship to flourish. Thus, SAFs are a product of existing institutional and cultural logics as well as new arrangements brought on by exogenous events.

Since SAFs emerge within existing fields (i.e., interstices ${ }^{2}$ ), explaining stability and change inherently means thinking about the environment of SAFs. For example, policy communities are fairly dependent (for actors, 
resources, etc.) on the broader institutional context of which they are a part. As a SAF, policy communities are influenced by a set of vertical relationships within committees as well as horizontal relationships between committees, including formal and informal ties between Congress and the executive branch, interest organizations, and activist networks. While a theory of fields includes important macro-level factors, there is a microfoundation to the theory whereby the work of social actors in promoting change is encouraged or discouraged by the normative order of SAFs. SAFs exist because of the behavior of socially skilled entrepreneurs. As Fligstein and McAdam claim, "It is the blend of preexisting rules, resources, and the social skills of actors that combine to produce fields in the first place, make them stable on a period to period basis, and produce transformation" ( $p$. 108). An important goal of strategic action is the creation of a shared capacity for viewing a problem. As strategic âction, entrepreneurship involves the ability of actors to create consensus around an issue through frame alignment as well as the mobilization of inside and outside actors into a coalition that assists in that effort.

\section{POLICY COMMUNITIES AND STRATEGIC ACTION FIELDS; SOCIAL SKILL AND POLITICAL ENTREPRENEURSHIP}

Policy communities are SAFs. They are "extra-formal interactions (i.e., interactions taking place beyond or outside the formal processes of government) that occur in the interstices between and among government agencies, interest groups, corporations, industry associations, elected officials, and other institutions and individuals. It is a grouping of interrelated policy actors pursuing a matter of public policy important to them for instrumental reasons" (Miller \& Demir, 2007a, p. 137). This definition alludes to three key points particularly as these pertain to SAFs. First, it denotes that policy communities emerge out of the interstice of actors and organizations both inside and outside the government. Second, it suggests that communities come about for shared purposeful and goal-oriented reasons by third, motivated instrumental actors (i.e., socially skilled entrepreneurs).

There are important distinctions between policy monopolies and policy communities. In the case of policy monopolies, the connection between congressional committees, agencies in the executive branch, and interest 
groups is tight-knit - hence the use of the term "iron triangle" (see Givel, 2006; McCarthy, 2005; True \& Utter, 2002).

Policy monopolies exist when a few elites or incumbents are able to maintain dominance over issues (issues that are generally bipartisan, nonsalient, and generate little conflict over issue framing) (see Baumgartner \& Jones, 1993; Rose \& Davies, 1994). There is little frame contestation here because elites do not face any real competition, and thus there is no need for entrepreneurship. On the other hand, policy communities are composed of looser coalitions of actors characterized by conflict and frame contestation by political entrepreneurs. Since communities suggest a wider array of actors from different sectors, it also means that outsiders or "challengers" can have access to agenda setting and, indirectly, to the policy-making process - access they would not otherwise have if an issue was largely tied to a policy monopoly. This is relevant to social movement scholars who have recently found that social movements have the most influence in the agendasetting stage of the legislative process rather than the final stages of legislative enactment (e.g., Johnson, Agnone, \& McCarthy, 2010; Olzak \& Soule, 2009).

Like SAFs, policy communities emerge as a result of broader institutional or environmental changes. Exogenous shocks may lead to political realignments and consequently shifts in the policy agenda which propel "disturbances" into a monopoly. The 1960s represents a critical juncture or, what Baumgartner and Jones (1993) refer to as, punctuation. Electoral turnover, policy shifts, and changes in public preferences not surprisingly created new opportunities for issue expansion. The activist government in the 1960s (Birkland, 2007; 2010; Mettler, 2007) created a "window of opportunity" for entrepreneurs to reshape the policy agenda (Kingdon, 1994). With the availability of new venues (such as congressional committees), political entrepreneurs are more freely able to contest policy images once promoted by monopolies. In these episodes of contention (Fligstein \& McAdam, 2012, p. 21), socially skilled entrepreneurs seek to elevate a frame above all other competing frames within a limited attention space. ${ }^{3}$ This typically requires convincing other interested actors of the problem, and proposed policy solutions (see Birkland, 2007; Cobb \& Elder, 1983; Carmines \& Stimson, 1989; Riker, 1982; Schattschneider, 1935). Thus, a large part of what entrepreneurs do involves persuasion, and their skills can be a function of their personality, their ability to relate to other actors, their position, status, and expertise, and the narrative ${ }^{4}$ they tell of the problem (see Atkinson \& Coleman, 1992; Baumgartner \& Jones, 1993; Jordan \& Maloney, 1997; Miller \& Demir, 2007b; Gottweiss, 2007; Polsby, 1984). Ultimately, the 
goal of persuasion is to make something that was contentious a taken for granted way of understanding a problem (Roa et al., 2000).

\section{DATA AND METHODS}

This paper seeks to situate the work of socially skilled actors - political entrepreneurs - within the policy communities in which they operate. In order to shed light on how a policy monopoly becomes a policy community, I use both original and existing data that describes the policy agenda in Congress between 1961 and 2006. This time period captures the rise of disability rights, as well as important legislation and subsequent decline in congressional interest. My analysis centers around three key variables: the number and type of disability-related hearings, the number and type of committees involved in disability, and the amount of policy output and change in the type of laws enacted by Congress.

Hearings are a measure of congressional interest in an issue. They are part of a legitimizing process of an issue by government where public frame contestation takes place (Burstein \& Hirsh, 2007; Costain, 1992; Gamson \& Modigliani, 1989; Johnson, 2008; King, Bentele, \& Soule, 2007). Hearings are held by committees which are the sites for political entrepreneurship (see Baughman, 2006; King, 1997; Smith \& Deering, 1990). Therefore, committee involvement on issues is an integral part of identifying policy communities (see Baumgartner \& Jones, 1993; Sheingate, 2006). The enactment of laws is the final stage of the policy process (with the possible exception of implementation which can lead to subsequent reframing and new policy, see Jann \& Wegrich, 2007). It is generally believed that in the final stages of the legislative process, actors can no longer reframe policy, nor do outsiders have influence on the outcome (Johnson, 2008; Johnson et al., 2010; King et al., 2007; Olzak \& Soule, 2009). Rather, entrepreneurial activity, the work of interest groups, and frame contestation and persuasion occur in the agenda-setting phase. In turn, agenda setting shapes policy output.

Information on disability-related hearings, committees, bills, and public laws is based on original longitudinal content analysis of Lexis-Nexis Congressional and the Congressional Record. I follow Burstein and Hirsh's (2007) strategy. First, I found all public laws related to disability using books, law reviews, and archives, as well as legislative information provided by numerous disability organizations. I then searched Lexis-Nexis 
Congressional to ensure that potentially relevant legislation was not overlooked. Once a sampling frame of laws was created, I content analyzed policies to verify that each policy is disability related. This produced a sample of 393 disability-related public laws. Using a preexisting general list of topics, as well as topics that emerged from my content analysis, I grouped the 393 laws into 10 categories: appropriations and budgets, health and human services, veterans, economic/labor/workforce, access and rights, blind/deaf, transportation, learning/developmentally disabled, elderly/social security, and technology. While I took into account that some policies address multiple issues, for the purposes of this paper, I use the dominant issue to group the policies.

Following Jones and Baumgartner (2004), King et al. (2007), and Johnson et al. (2010), I used a yearly count of hearings as a measure of issue attention by Congress. With a population of public laws, I was able to compile a list of all the hearings associated with those laws. I used the legislative history of laws which includes the bills associated with those laws to create a sampling frame of hearings. I then content analyzed those hearings to determine their main focus as well as to eliminate any duplicates (including joint hearings). I then used the Congressional Record and Lexis-Nexis Congressional to find hearings not associated with specific laws or bills. ${ }^{5}$ This produced a total of 1275 hearings ( 875 House hearings, 400 Senate hearings). Once a list of bills, hearings, and laws was compiled, I was then able to determine the number and type of committees and subcommittees that were interested in disability-related issues over time, as well as the ways in which the focus of attention shifted in that 45 -year period.

I complemented my data with Baumgartner and Jones' comprehensive policy agenda data. The Policy Agendas Project (www.policagendas.org) uses topic and subtopic codes, which allowed me to link my disability-related hearings and policy data with theirs. There are five disability-relevant subtopic codes in the Policy Agendas Project codebook: handicap/disease discrimination (205), mental health/retardation (333), long-term care, home health, terminally ill, and rehabilitation services (334), special education (606), and assistance to disabled/handicapped (1304). Unfortunately, given the magnitude of their data gathering effort, they tend to underestimate or code differently those hearings that have important disability-related implications. However, the benefit of linking my data to theirs is that it allowed me to compare disability to other issues in the policy agenda. In Fig. 2, I used the number of social welfare-related hearings from the Policy Agendas Project (topic code 13) to illustrate the rise of the welfare state. Social welfare includes the following subtopics: food stamps, food assistance, 
and nutrition monitoring programs (1301), poverty and assistance for lowincome families (1302), elderly issues and elderly assistance programs (including social security administration) (1303), assistance to the disabled and handicapped (1304), and social services and volunteer associations (1305). I used the same topic code for the bill sponsorship data presented in Fig. 2 which is from Adler and Wilkerson's Congressional Bills Project (www.congressionalbills.org).

\section{INNOVATION IN DISABILITY: HOW ENTREPRENEURS IN A SAF PROMOTED A RIGHTS AGENDA}

Political and institutional entrepreneurs have no doubt played a role in numerous social movements and issues: from race (Santoro \& McGuire, 1997) to the environment (Reichman \& Canan, 2003) to women's rights and gender (Banaszak, 2005, 2010). Entrepreneurship is particularly important in understanding the rise of disability rights in the United States for two main reasons. First, there is little evidence that either changes in objective conditions (such as employment, earnings, or health outcomes) or changes in public preferences specifically related to disability drove government action. Second, when entrepreneurs began to shift political discourse away from social services and vocational rehabilitation toward rights, there was no social movement pressuring the government to pursue such action. The movement for rights largely began in the government (see Scotch, 2001; Skrentny, 2002).

Despite the lack of these demand-side factors, disability has always had a place on the policy agenda. This is rather unlike issues of race, gender, and the environment, all of which experienced protracted periods of no government attention especially before the 1970s (see Costain, 1992; Johnson, 2008). As Fig. 1 shows, the government was already paying attention to disability well before there was a disability rights movement, and well before the passage of key policies like the Rehabilitation Act of 1973 or the Americans with Disabilities Act (ADA) of 1990. But, before the late 1960s, much of the policy agenda was controlled by a tightly knit policy monopoly promoting either a medical model or client-service model of disability, not rights or equality. Fig. 1 also indicates an expansion of attention beginning in the 1960s which continued into the 1970s and 1980s. It was at this critical juncture or period of punctuation that entrepreneurs 


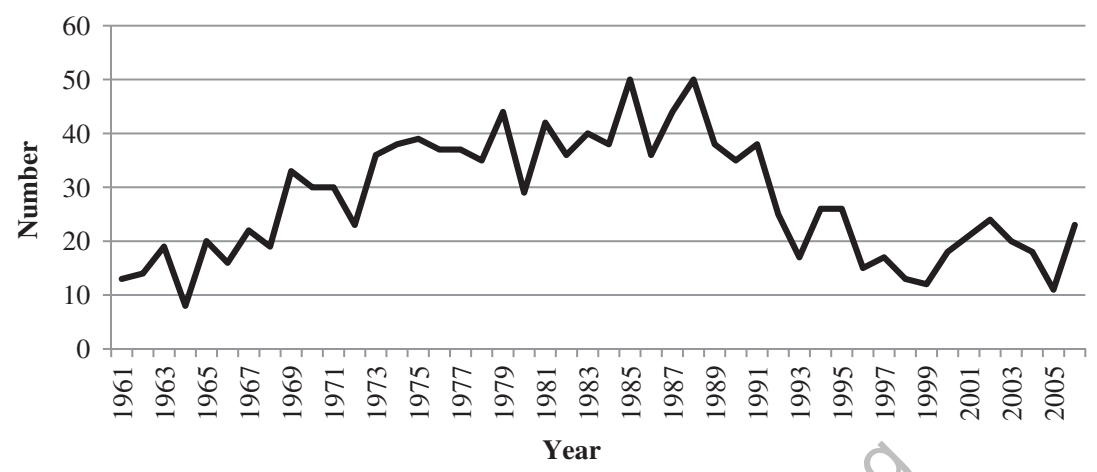

Fig. 1. Disability-Related Hearings Between 1961 and $2006(n=1275)$.

were able to pursue rights. In order to understand the expansion of disability rights, it is important to describe the context that facilitated political entrepreneurship including broad environmental changes, the rise of policy communities, and the new actors that became part of that community who championed rights.

The Extant Disability Policy Monopoly and Policy Image

For much of U.S. history, discourse surrounding disability focused mainly on health, social, and rehabilitative services. Not only was the government's attention narrow, but so too was the constituency that benefited from these resulting policies, namely veterans, the deaf, blind, and to a lesser extent, individuals with mental/developmental disabilities. For example, important legislation like the Smith-Fess Act of 1920 created vocational rehabilitation for the disabled. After the New Deal, policies like the Randolph-Sheppard Act were enacted to deal with massive unemployment among the blind. The following decades saw similar measures: the 1944 GI Bill, Truman's Employ the Physically Handicapped Week of 1945, and the Vocational Rehabilitation Act of 1954. In 1961, the Kennedy Administration created the President's Panel on Mental Retardation and signed the Maternal and Child Health and Mental Retardation Planning Bill in 1963. Other disabilityrelated policies of the 1960s include National Technical Institute for the Deaf Act of 1965, Social Security Amendments of 1967, Urban Mass Transportation Act of 1964, and the Vocational Rehabilitation Act Amendments of 1967 and 1968. Thus, government's involvement in 
disability grew alongside the government's increasing role in social welfare. As Scotch (2001, p. 24) notes, "The concept of rehabilitation was at the core of the ideology of the emerging American welfare state."

Political elites in Congress and in the executive branch (namely the Rehabilitative Services Administration, aka, RSA) expanded rehabilitation programs in the 1950s and early 1960s. It is within this context that a tightly knit policy monopoly emerged and sustained itself. As the government promoted an image of rehabilitation and social service, not surprisingly, disability groups (usually not run by people with disabilities) like Muscular Dystrophy Association, March of Dimes, National Society of Crippled Children, and the Easter Seals (see Longmore, 2003) were largely interested in service provision complementing the policy image of the time (see Skocpol, 2007). In the early to mid-1960s, some of the more involved disability organizations (based on their participation in congressional hearings) included the National Federation of the Blind, Paralyzed Veterans of America, Easter Seals, National Society for Crippled Children and Adults, National Association of the Physically Handicapped, National Association for Retarded Children, United Cerebral Palsy, and the National Association for the Deaf. These established groups are in Gamson's (1975) terms, "innocuous," incumbent or state-legitimated elite organizations that had fairly close ties to health and social service professionals, politicians, and administrative agencies, and were often involved in protecting or extending social services through the political process. As Scotch (2001, p. 34) claims, although existing disability organizations "had varying degrees of political involvement ... none was oriented toward the general issue of civil rights for all disabled people."

Numerous professional organizations were part of this monopoly and were heavily involved in setting the agenda. These include the National Association of State Directors of Special Education, the National Association of Sheltered Workshops, the Conference of Executives of American Schools for the Deaf, the American Medical Association, the American Optometric Association, the Council of State Administrators of Vocational Rehabilitation, and the National Institutes on Rehabilitation and Health Services. Disability and professional groups were joined by key members of the executive branch, namely representatives from the RSA and the Department of Health, Education, and Welfare (HEW). Together, they formed a policy monopoly ensuring the expansion of health and social welfare services - a policy image that went largely uncontested. Indeed, a major obstacle for the emergence of a disability rights movement and advocacy organizations was what Berkowitz (1987) calls the "rehabilitationists." 
The view often promoted by this policy monopoly was one based on the belief that "disabled people accommodate society rather than society accommodate them" (O'Brien, 2001, p. 5).

This began to change in the late 1960s and early 1970s with an increasing amount of attention on disability-related issues as a result of exogenous factors that shook the overall policy agenda. Not only was attention to disability increasing in this period, but it was also becoming more complex, touching on a variety of other issues like transportation, civil rights, education, housing, and technology.

\section{Exogenous Shocks: The Rise of Activist Government}

As institutional scholars (see for instance, Pierson 2007). Have long noted, the 1960s and 1970s saw an expansion of the American welfare state (see Fig. 2). The Democratic Party played an active role shaping the policy agenda and politicizing a variety of social issues. As Nick Edes, a staffer for Harrison Williams and disability rights entrepreneur, claimed (in Scotch, 2001, p. 47):

You have to understand that the 1970s began really the emergence of the Congress as an institution in really initiating substantial amounts of social policy, important social policy .... We in the Congress therefore as a matter of self-defense and as a matter of Democratic Party politics felt that it was important to take the initiative because otherwise the initiative would not be taken elsewhere.

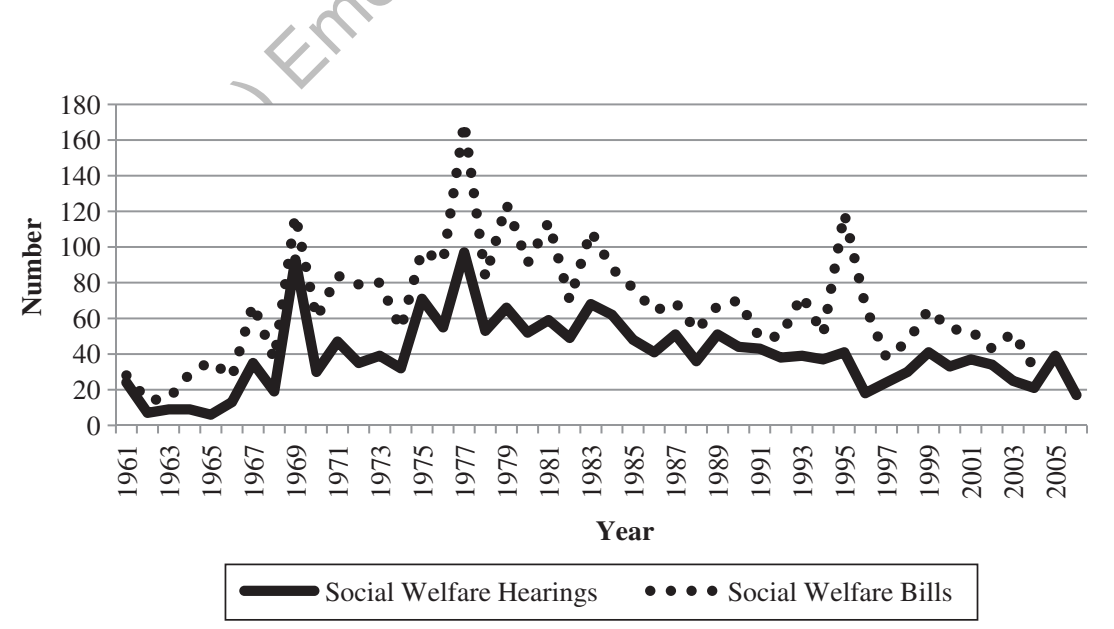

Fig. 2. Social Welfare-Related Hearings $(n=1919)$ and Bills $(n=1199)$ Between 1961 and 2006. 
Part of the Democrats' success in pursing social and social welfare issues involved not only ideological changes but procedural ones as well. Young Democrats worked to change the rules surrounding committee assignments which had been historically based on seniority, what Polsby (2004) refers to as "liberalization" of congressional rules and norms. Generally, southern Democrats who had the most seniority and thus occupied key positions on a variety of committees were obstacles to the Great Society projects. Eventually, younger liberals changed the balance in the House Democratic Caucus and worked to replace senior conservative southern Democrats. With this, new venues became available for a host of social issues on which entrepreneurs sought to stake a claim. It is thus not surprising that Baumgartner and Jones (1993) find that social welfare became an increasingly larger share of the policy agenda at this time. This had an important impact on legislative activity of the time that came to define the Great Society like the Civil Rights Act and Older Americans Act, and new social programs like the Job Corps, the Neighborhood Youth Corps, Head Start, Upward Bound, and Medicare/Medicaid. It is no wonder that Levitan and Taggart (1976, p. 29) refer to the role of the federal government at this time "as a lever of institutional change."

The executive branch also became more active in social policy as legislators and their aides forged ties with sympathetic elites in the executive, thus ensuring a close relationship between policy creation and implementation. For instance, HEW's assistant secretary, Wilber Cohen, led a 1960 task force which proposed that Aid to Families with Dependent Children (AFDC) coverage should be extended and Congress approved the extension in 1961 (Patterson, 2000). HEW also created the Special Staff on Aging. As Patterson (2000, p. 182) describes, "HEW ... was a liberal bureaucracy with every reason to aggrandize itself." Indeed, the Office of Civil Rights (OCR) within HEW played a critical role in interpreting and expanding the rights provisions of the Rehabilitation Act. The OCR was sympathetic to, and entrepreneurial on, disability rights while the rest of the executive, including HEW as a whole, began to express doubts over the intent of Section $504^{6}$ of the Rehabilitation Act.

\section{From Policy Monopoly to Policy Community}

As the federal government became involved in an increasing number of social issues (Baumgartner \& Jones, 1993; Campbell, 2005; Skocpol, 2007), those issues expanded and became more complex. Issue expansion is facilitated by the increasing availability of new venues for political discourse 
(such as congressional committees and executive branch offices) as well as entrepreneurs interested in staking a claim on issues. Disability was no exception.

In 1961, only three House committees held disability-related hearings: Veteran's Affairs, Appropriations, and Education and Workforce. A similar situation existed in the Senate. Indeed, the Committee on Health, Education, Labor and Pensions - a committee that becomes an important site for the rise of disability rights and which will contain the Subcommittee on the Handicapped - held no hearings in 1961, and virtually no hearings in the first 5 years of the decade. By the late 1960s, there was an expansion in the number of committees holding disability-related hearings. Fig. 3 depicts the increase in the percent of all Senate and House committees holding disability-related hearings. Note that the Senate experienced an increase first, followed by the House. This conforms to expectations about the Senate being more entrepreneurial than the House (see Sulkin, 2005). By the late 1970s, the number of Senate committees holding disability-related hearings doubled. In the House, more than half of all committees were holding disability-related hearings by the early 1980 s.

Following the Architectural Barriers Act of 1968, a range of committees began to hold hearings. While most of the hearings surrounding the Architectural Barriers Act were held before the House Committee on Public Works, a significant portion of hearings were also held by the House Committee on Labor and Public Welfare (where access and equal rights

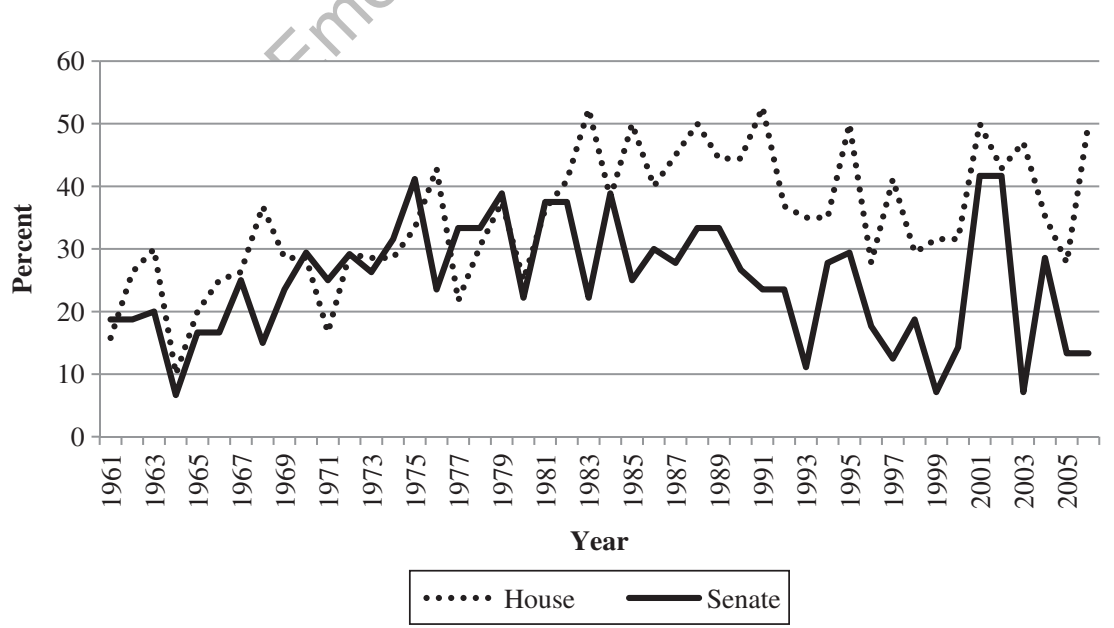

Fig. 3. Percentage of Committees Holding Disability-Related Hearings, 1961-2006. 
became much more of a concern especially with the Rehabilitation Act). A similar situation emerged with public transportation. Three different committees became involved in the issue of access to transportation in the 1960s and 1970s: the Senate Committee on Labor and Public Welfare (mainly the Subcommittee on Handicapped), the House Committee on Banking and Currency, and the House Committee on Public Works.

In a context of growing government involvement, entrepreneurs became specialists on various facets of disability, further expanding the issue across various committees. In the House, the Committee on Energy and Commerce, the Committee on Science, Space, and Technology, and the Committee on House Oversight and Government Reform all heard numerous disabilityrelated hearings. In the Senate, interest increased within the Committee on Government Affairs, the Committee on Environment and Public Works, and the Committee on Commerce, Science, and Transportation.

Attention to disability by committees sheds light on how committees contribute to issue expansion in the policy agenda. Some committees maintain consistent interest in an issue while others see bursts of attention. As Fig. 4 illustrates, only the Senate Labor and Public Welfare Committee
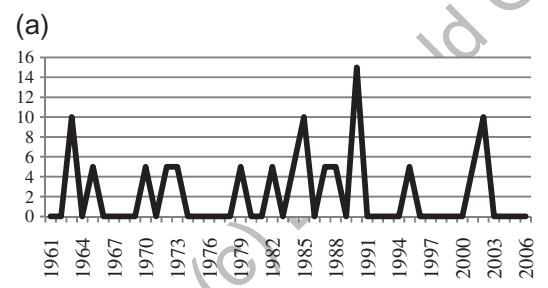

(c)

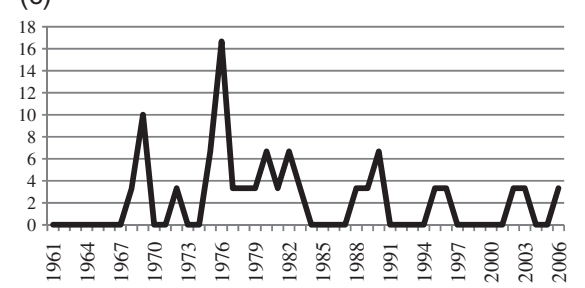

(b)

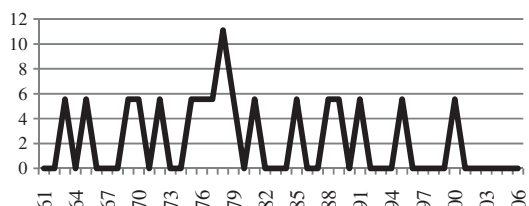

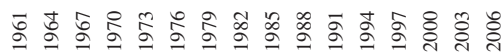

(d)

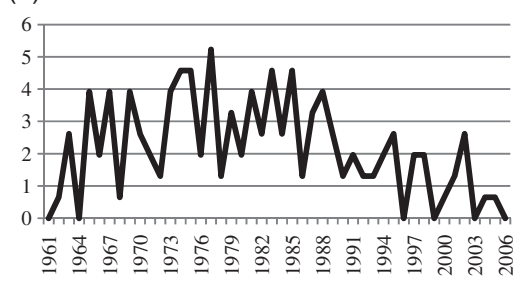

Fig. 4. (a) Hearings: House Committee on Financial Services (aka, Banking and Currency). (b) Hearings: Senate Committee on Banking, Housing, and Urban Affairs. (c) Hearings: House Committee on Transportation and Infrastructure (aka, Public Works). (d) Hearings: Senate Committee on Health, Education, Labor, and Pensions (aka, Labor and Pubic Welfare). 
seems to approximate the general pattern of disability issue attention shown in Fig. 1. Other committees holding disability-related hearings demonstrate much more punctuated interest. This suggests that with exogenous shocks when there is a normative shift and issue disorganization ensues - some committees not typically interested in an issue begin to hold more hearings because entrepreneurs may see a window of opportunity to stake a claim on new aspects of an issue (see King, 1997), but then return to paying no attention. Committees more invested in the issue (like Labor and Public Welfare) may not experience "bursts" but still, despite their consistent attention, see and ebb and flow in interest. In the 1990s, this committee saw a significant decline in hearings.

The late 1960s and early 1970s represent a critical juncture for disability a period of punctuation that saw a breakdown in the existing arrangement that promoted a client-service policy image of disability. As disability became a larger, more multifaceted political issue in the late 1960s and 1970s, new actors and new venues began to erode the policy monopoly that had long existed. Not surprisingly, the increasing number of committees corresponds to the rise in the amount of attention disability received in Congress.

\section{The Role of Disability Rights Entrepreneurs}

Senators Bob Bartlett, Hubert Humphrey, Harrison Williams, their aides, like the aforementioned Nick Edes, and members of the executive, like deputy director of the OCR, Martin Gerry, are political entrepreneurs. These are strategic/actors who played an important role within an expanding policy community in ensuring that a rights frame continue to be a prominent image of disability policy. In fact, many entrepreneurs saw themselves as such. For instance, Robert Humphreys, who was Senator Jennings Randolph's aide, claimed that Section 504 was "essentially selfgenerated on the part of staff of the [Labor and Public Welfare] committee." In a similar vein, Nick Edes refered to Senate staffers as "the Martin Luther Kings of the disability movements on Capitol Hill and in the government." He claimed that the disablility rights movement emerged out of the work of these institutional entrepreneurs: "The movement [of disabled people] was stimulated by the acts of a very few individuals who were in the legislative branch" (Scotch, 2001, p. 57).

Altman and Barnartt (1993) note that disability moral entrepreneurs were often not those with impairments but were, in some ways, considered experts (i.e., "the wise") on disability. I find that disability entrepreneurs 
share three common characteristics: their personal connections to disability, their policy experience with the Great Society, and their political/ professional ambitions and aggrandizement.

Anecdotes and personal experiences regarding disability were often part of entrepreneurs' narrative. Many disability rights entrepreneurs had personal connections to disability (a friend or family member). A major impetus for Bartlett's Architectural Barriers Act was that his legislative aide was denied access to the National Gallery because the gallery was not accessible to wheelchair users (Katzmann, 1986). Entrepreneurs were also influenced by the changing policy agenda of the 1960s. Hubert Humphrey (whose granddaughter had Down syndrome), who along with Representative Charles Vanik introduced an amendment to the Givil Rights Act to include disability as grounds for discrimination, not surprisingly had been involved with a variety of social policies including the Civil Rights Act. Indeed, many disability rights entrepreneurs had general experience with health and social welfare policies (although not necessarily specific experience with handicap and disability), and to a lesser extent civil rights.

Politicians "need" issues as a way to get onto committees and gain prominence in Congress (Sulkin, 2005). Some elites were entrepreneurial because they saw disability as a safe issue with few political opponents. For example, Mario Biaggi (Democratic Representative from New York) had no prior interest in disability and had no connection to the House Public Works and Transportation Committee which had been dealing with access to transportation. Nonetheless, Biaggi proposed an amendment to the Mass Transportation Act such that the disabled "have the same right as other persons to utilize mass transportation ... that special efforts be made in the planning and design of mass transportation facilities ...." According to Katzmann (1986) who interviewed Biaggi's assistant, Peter Ilchuck, Biaggi was a newly elected politician looking for an issue to champion. Disability was also an issue that agencies in the executive branch saw as a way to professionally aggrandize. For example, Martin Gerry who headed the OCR in HEW believed strongly in equal rights for the disabled and saw the assignment of the Rehabilitation Act regulations as a way to expand the OCR's jurisdiction to a new constituency. Indeed, John Wodatch, who had been put in charge of Section 504, felt that the "job provided him with a good opportunity to be in charge of a big project from start to finish and to gain experience with policy development" (Scotch, 2001, p. 64).

Disability rights entrepreneurship in both the Senate and House is a salient example of the connection between strategic actors and the venues within which they act. In the Senate, Harrison Williams created the Subcommittee 
on the Handicapped in 1972 when he was the Committee on Labor and Public Welfare chair. As Scotch (2001 p. 50) notes, when Williams became chair "he picked up disability as an area which no one in the Senate was working in a concentrated way." He also went on to become a prominent figure in the Senate Committee on Banking, Housing, and Urban Affairs. In promoting the Biaggi Amendment, Williams made the rights frame central to that committee. Williams held hearings under the Subcommittee on Housing and Urban Affairs which now included disability groups who had not previously seen this committee as a venue for disability issues. He also championed the OCR as the executive branch agency best suited to write and implement Section 504 regulations.

At the same time, reorganization in the House saw the Public Works Committee assume control over transportation from the Committee on Banking and Currency. This has important consequences because the Public Works Committee was more rights oriented and committee chair, Kenneth Gray, was a major proponent of equal rights and equal access. In the early 1970s, John Brademas, a key supporter of the Rehabilitation Act, became chair of the House Committee on Education and Workforce. Together with Williams in the Senate and other members of Congress, they in effect created a community of staffers who were critical in forging ties with the executive and promoting disability rights often under the radar. It was entrepreneurial staffers and aides who ensured that the civil rights language in the Humphrey-Vanik bill was inserted into the Vocational Rehabilitation Act Amendments. Legislative staffers and executive branch members also formed close relationships with the nascent disability rights movement. Judy Heumann, founder of one of the first modern cross-disability protest groups, Disabled in Action (DIA) (see Barnartt \& Scotch, 2001), interned for Lisa Walker, a staffer for both Brademas and Williams. Entrepreneurs in the executive branch, including Gerry, encouraged protests at HEW offices when David Matthews, the new HEW secretary, was reluctant to act on Section 504.

In the 1960s and 1970s, disability exploded as an issue. With the proliferation of new venues focusing on a variety of disability-related issues, new groups and actors were able to join incumbents in promoting social change. With increasing government attention to rights, existing disability groups as well as newly formed organizations became increasingly focused on advocacy, and in some cases protest, rather than service provision. The rise of this broader disability policy community, to use McCarthy's (2005) Velcro analogy, created a looser set of relationships which facilitated the ability of actors, including SMOs, to come in and out of the political process. 


\section{Policy Consequences}

Institutional changes that led to a reconfiguration of actors and venues that is, the collapse of a monopoly and the rise of a community - had important policy implications. First, the increase in the amount of attention disability received on the policy agenda corresponds to an overall increase in legislative activity. The amount of attention disability has received from the federal government differs from other issues and constituencies in that there has never really been protracted periods with no attention. For instance, gender (see Costain, 1992) and race (see Carmines \& Stimson, 1989) have had extended periods with little to no legislative activity. As Fig. 5 shows, the 1960s already begins with 15 disability-related laws enacted. In fact, the first 5 years of the 1960s saw more than 45 public laws enacted that relate to disability. Despite starting out with an already elêvated baseline of policy output, the 1960s and 1970s did experience an increase in the amount of legislative activity that remained relatively high until about the passage of the ADA in 1990.

Second, there is a qualitative shift in the types of laws being enacted given the rise of a policy community promoting new policy images. More than half of all public laws passed in this 45-year period are related to appropriations and the budget, veterans, or health and human services, reflecting the location of a majority of disability-related hearings in those

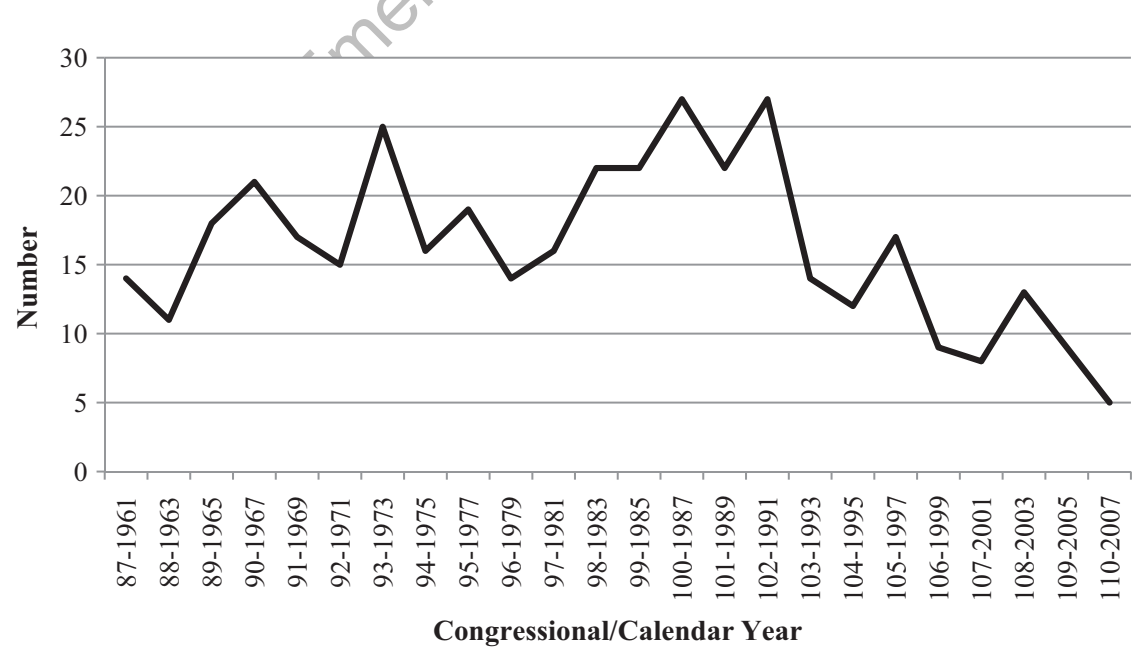

Fig. 5. Disability-Related Public Laws by Congressional Year and Calendar Year $(n=393)$. 
specific committees. Although health- and- human- services- related legislation saw a small peak in the 1970s, it remained a significant proportion of legislative activity between 1961 and 2006. Other issues, some of which had been a central part of the disability policy monopoly like policies aimed at the deaf and blind as well as economic policies regarding vocational rehabilitation and labor force participation, experienced a sharp decline. However, access and rights related legislation (see Fig. 6) saw significant increases in the 1970s and again in the late 1980s just prior to the passage of the ADA. Both of these legislative peaks coincide with punctuation in congressional attention to disability. While rights and access represent only 8 percent of all disability-related policies enacted between 1961 and 2006, the work of entrepreneurs within an expanding policy community influenced the rise of rights-related legislation between 1970 and 1990 .

In the 1960s, political entrepreneurs, both in Congress and within government agencies, began to frame the problem of accessibility for the handicapped in terms of rights. Their ability to do this was brought on by exogenous shocks such as the rise of the Democratic Coalition and the Great Society of the 1960s, as well as the changing norms about committee assignments that eventually led to a collapse of the disability policy monopoly that had, in many ways, served as an obstacle to rights. This allowed for the emergence of new venues and new actors (both insiders and outsiders) who promoted rights in the government.

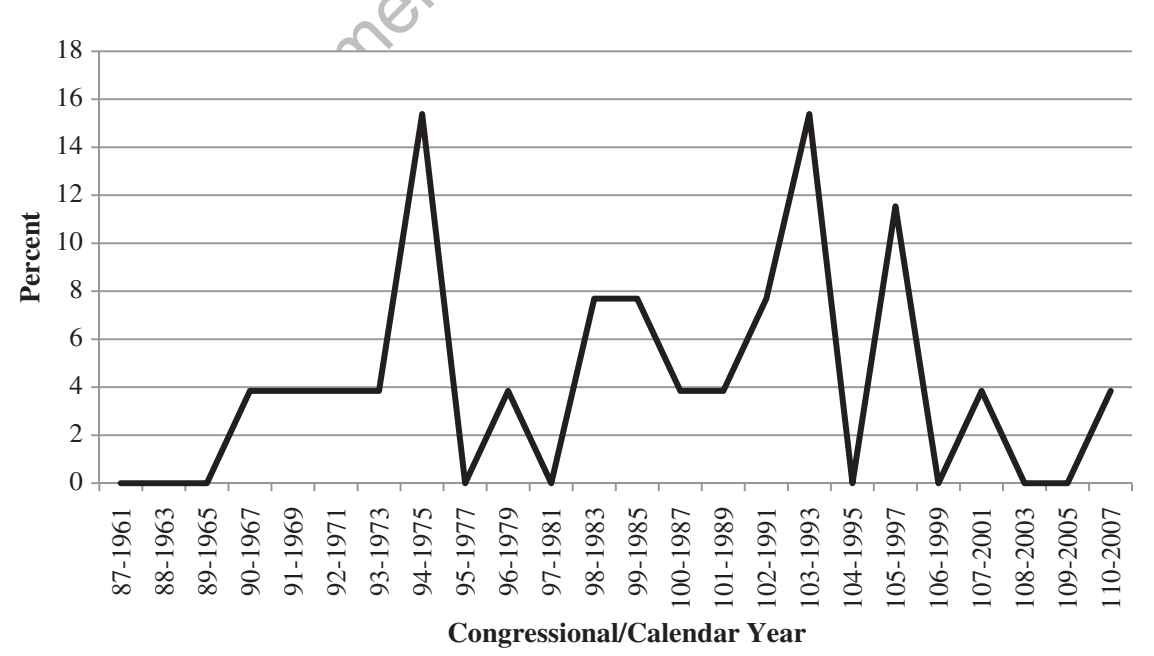

Fig. 6. Percentage of Policies Related to Access and Rights for the Disabled by Congressional Year and Calendar Year. 


\section{DISCUSSION}

The primary objective of this paper is to explain the relationship between insiders and outsiders and the context within which they interact. The paper speaks to the renewed and growing interest in the social movement literature on the role of strategic social movement actors and the grassroots and institutional contexts within which they promote change (see Downey \& Rohlinger, 2008). However, I also depart from traditional social movement and democratic theories by focusing on specific supplyside factors that contribute to sociopolitical change. I draw from the recent trend in neo-institutional theory that focuses on meso-level social orders. This provides a useful framework for understanding the dynamic link between political elites in the elected and executive branches, incumbent and challenging groups, and the venues that facilitate entrepreneurial behavior.

The expansion of disability on the policy agenda and the rise of a disability rights policy image showcase the importance of the institutional context of social change. The late 1960s and 1970s saw punctuation brought on by exogenous shock. This led to the collapse of a policy monopoly that had promoted a narrow policy framing of disability giving way to the rise of a more heterogeneous policy community. This had important consequences for disability. It established new venues for disability political discourse; it facilitated entrepreneurial behavior which led to further issue expansion, including the rise of a rights frame; and it brought in new actors, including newly formed disability SMOs. Consequently, the rise of a disability policy community and the expansion of disability in Congress reshaped disabilityrelated legislative activity.

As SAFs, policy communities are a loose but organized set of relationships between socially skilled actors or entrepreneurs with a common understanding and interest in an issue that come together in a tight space between other preexisting fields: Congress, the executive branch, professional associations, nonprofit organizations, and SMOs. SAFs are therefore embedded within broader institutional contexts. Stability or equilibrium creates a situation whereby a tightly knit group of politicians, bureaucrats, professionals, and interest organizations promote a particular policy image that goes largely unchallenged. In the case of disability, key actors confined to limited venues promoted the dominant image of the client-service model of handicap. But the 1960s saw a reconfiguration of the political landscape. Whether exogenous shock in Fligstein and McAdam's (2012) terms, a critical juncture in terms of historical institutionalism (Thelan, 1999), or 
punctuation for Baumgartner and Jones' (1993), institutional changes created disorganization in the policy agenda. It is under these conditions that entrepreneurship flourishes. This suggests that political entrepreneurship, as Fligstein and McAdam $(2011,2012)$ claim, is more relevant for transformation than it is for reproduction of the status quo. Entrepreneurs matter more in disorganized social spaces - that is, when fields are new or emerging, not when they are settled.

There are three additional takeaway points alluded to in this paper. The first is in relation to the ways in which SAFs like policy communities democratize social change. There is often a negative connotation surrounding supply-side explanations for social change. Concepts like "democracy from above," "overhead democracy," and "juridical democracy" are sometimes used in conjunction with political entrepreneurship (see King, 1997), suggesting that the public has no say on social policy when entrepreneurs are involved. However, the public cannot be consistently aware of, or interested in, all the issues on the policy agenda, especially since Congress has dealt with an increasing number and complexity of issues. For instance, it is unlikely that rehabilitation and social service provision for the handicapped were on the minds of most Americans in the 1950s and 1960s. Should that preclude government from dealing with such issues? It may very well be the case that when policy monopolies exist, outside interests will not have much influence on political discourse. However, entrepreneurship does not erode pluralism but may actually encourage it by dismantling much more restrictive monopolies. Policy communities create more entry points for diverse actors and ideas. This signals a new political opportunity for SMOs such that they gain access to the policy process and become part of the SAF that shapes the policy agenda.

Second, the implication of the theory and data I present here is that disability rights is a political innovation that had much more to do with entrepreneurship and institutional activism than outside mobilization or shifts in public opinion. Nevertheless, as the government became increasingly interested in rights, especially by enacting the Rehabilitation Act, it reshaped its interaction with the disability community. Indeed, this is a case of policies creating citizens (Campbell, 2005). The proliferation of advocacy organizations and the sustained use of direct action followed from the Rehabilitation Act; it did not precede it. And, the dissemination of a rights framework to activists, advocates, disabled constituents, and the general public occurred primarily when entrepreneurs, especially those in the OCR, appealed to "outsiders" to pressure the secretary of HEW to pass Rehabilitation Act regulations. 
Finally, while the theory of fields focuses mostly on the emergence of SAFs and the policy literature on the collapse of monopolies and the rise of communities, there is less attention on what occurs to SAFs or policy communities over time. Issues eventually decline in saliency both inside and outside government as entrepreneurs successfully make certain policy images taken-for-granted (Baumgartner \& Jones, 1993; Jones \& Baumgartner, 2005). Only a core set of actors will continue their involvement in policy monitoring. As McCarthy's (2005) Velcro triangles suggest, other actors will most likely move onto other issues either within or outside of government. Following the ADA, disability declined as an issue in Congress and became concentrated around a few key issues. Committee involvement also became more sporadic and failed to generate greater attention to disability within Congress (as is indicated by the sharp decline in hearings; see Fig. 1). With a decline in the number of issues and venues, fewer disability groups were involved in the policy process at the federal level.

An important objective of the paper is to build on the theory of fields using the case of disability rights at the federal level. The paper has two important limitations. First, I focus exclusively on entrepreneurship as it pertains to federal politics surrounding disability. I do not analyze local or state-level politics. No doubt, entrepreneurs may also be critical within state legislatures especially given that between the early 1970s and the late 1980s, many states had enacted some form of rights-based/antidiscrimination disability legislation. Second, while there is a decline in congressional attention on disability, this may be a result of a shifting focus away from legislative politics to judicial politics. Following the ADA, the courts became an important site of conflict over interpretation of congressional intent regarding the ADA and other federal legislation. Nevertheless, federal politics set in motion a new political orientation particularly around rights and this helped generate a new political constituency that mobilized around a new policy image.

This paper brings together themes and concepts from diverse but related literatures including political sociology, political science, policy research, and social movements to shed light on the role institutional entrepreneurs play in generating issue attention. Political scientists and sociologists have often written about the impregnability of iron triangles but the static nature of its application ignored how monopolies over issues emerge and how they decline (Baumgartner \& Jones, 1993). Policy scholars in the 1960s and 1970s came to recognize the importance of the coalition of actors inside and outside of the legislature that form policy communities (Fenno, 1977; Lowi, 1964). As movement scholars became increasingly interested in specific 
linkages between social movements and policy, they too recognized the community of incumbents and challengers that come in and out of the political process (i.e., McCarthy's (2005) Velcro triangles).

There are also conceptual overlaps between what political scientists and policy scholars refer to as political/policy entrepreneurs and what movement scholars call institutional activists. But, there are also important differences. Unlike the more demand-side understanding of institutional activist (see Banaszak, 2005, 2010; Katzenstein, 1998; Santoro \& McGuire, 1997; Tilly, 1978), political entrepreneurship does not assume that political elites are responding constituents' demands or that they were or are movement activists (Baumgartner \& Jones, 1993; Costain \& Majstrovic, 1994; King, 1997; Pettinicchio, 2012; Reichman \& Canan, 2003; Sheingate, 2006; Sulkin, 2005). That is, as Wawro (2001) argues, even elected entrepreneurs have a certain degree of freedom in building legislative programs. Entrepreneurs can play a critical role in bringing in movement actors and organizations as they are often required to mobilize outsiders for support (Baumgartner \& Jones, 1993; Cobb \& Elder, 1983; Fligstein \& McAdam, 2011, 2012). This paper sheds light on how supply- and demand-side perspectives come together in explaining sociopolitical change. As strategic actors who "innovate, propagate, and organize" (Fligstein \& McAdam, 2012, p. 4), political entrepreneurs are critical in promoting change within policy communities.

\section{NOTES}

1. The extent to which changes from exogenous shocks are felt depends on the SAFs' proximity to the changes taking place.

2. An interstice, as defined by Roa et al. (2000, p. 252), "is a gap between multiple industries or professions and arises when problems or issues persistently spill over from one organizational field to another." It is a field that, given the complexity or size of an issue, brings in numerous players from different fields whose interests overlap on a given issue. Their discussion of interstices also alludes to the importance of entrepreneurs in bringing in various actors into SAFs.

3. Baumgartner and Jones (2005) suggest that boundedly rational actors, who have become increasingly specialized on issues, disproportionately focus on certain kinds of information given that there is so much of it and a limited attention span.

4. As van Eeten (2007) and Roe (1994) explain, policy narratives are stories (see also Stone, 2002), which can emphasize the casual or personal, the pragmatic, or the logistics of a problem.

5. Note that not all bills or hearings are associated with a specific policy. Often, committees hold hearings as a way to establish a claim on an issue so as to then influence committee bill referrals by parliamentarians (see King, 1997). 
6. Section 504 states: "No otherwise qualified handicapped individual in the United States shall, solely by reason of his handicap, be excluded from the participation in, be denied the benefits of, or be subjected to discrimination under any program or activity receiving Federal financial assistance."

\section{ACKNOWLEDGMENTS}

The idea for this paper came about from a conversation with Mayer Zald at the 2011 Young Scholars in Social Movements Conference. I am forever grateful for his advice. I would also like to thank Robert Crutchfield, Steven Pfaff, Edgar Kiser, Debra Minkoff, and Suzanne Staggenborg for their feedback on different versions of this paper.

\section{REFERENCES}

Altman, B., \& Barnartt, S. N. (1993). Moral entrepreneurship and the passage of the ADA. Journal of Disability Policy Studies, 4, $21-40$.

Atkinson, M. M., \& Coleman, W. D. (1992). Policy networks, policy communities, and the problems of governance. Governance, 2, 154-180.

Banaszak, L. A. (2005). Inside and outside the state: Movement insider status, tactics, and public policy achievements. In D. S. Meyer, V. Jenness \& H. Ingram (Eds.), Routing the opposition: Social movements, public policy and democracy (pp. 149-176). Minneapolis, MN: University of Minnesota Press.

Banaszak, L. A. (2010). The women's movement inside and outside the state. New York, NY: Cambridge University Press.

Barnartt, S. N., \&-Scotch, R. (2001). Contentious politics, 1970-1990. Washington, DC: Gallaudet University Press.

Baughman, J. (2006). Common ground. Stanford, CA: Stanford University Press.

Baumgartner, F. R., \& Jones, B. D. (1993). Agenda and instability in American politics. Chicago, IL: University of Chicago Press.

Berkowitz, E. D. (1987). Disabled policy: America's programs for the handicapped. Cambridge, MA: Cambridge University Press.

Birkland, T. A. (2007). Agenda setting in public policy. In F. Fischer, G. J. Miller \& M. S. Sidney (Eds.), Handbook of public policy analysis: Theory, politics and methods (pp. 63-78). New York, NY: Taylor and Francis.

Birkland, T. A. (2010). An Introduction to the policy process. Armonk, NY: M.E. Sharpe.

Burstein, P., \& Hirsh, C. E. (2007). Interest organizations, information, and policy innovation in the U.S. Congress. Sociological Forum, 22, 174-199.

Campbell, A. L. (2005). How policies make citizens: Senior political activism and the American welfare state. Princeton, NJ: Princeton University Press.

Carmines, E. G., \& Stimson, J. A. (1989). Issue evolution: Race and the transformation of American politics. Princeton, NJ: Princeton University Press. 
Cobb, R. W., \& Elder, C. D. (1983). Participation in American politics: The dynamics of agenda building (2nd ed.). Baltimore, MD: Johns Hopkins University Press.

Costain, A. N. (1992). Inviting women's rebellion. Baltimore, MD: Johns Hopkins University Press.

Costain, A. N., \& Majstrovic, S. (1994). Congress, social movements and public opinion: Multiple origins of women's rights legislation. Political Research Quarterly, 47, 111-135.

DiMaggio, P. J., \& Powell, W. W. (1983). The iron cage revisited: Institutional isomorphism and collective rationality in organizational fields. American Sociological Review, 48, 147-160.

Downey, D. J., \& Rohlinger, D. A. (2008). Linking strategic choice with macro-organizational dynamics: Strategy and social movement articulation. In P. G. Coy (Ed.), Research in social movements, conflicts and change (vol. 28, pp. 3-38). Bingley, UK: Emerald.

Fenno, R. F., Jr. (1977). U.S. House members in their constituencies: An exploration. American Political Science Review, 71, 883-917.

Fligstein, N., \& McAdam, D. (2011). Toward a general theory of strategic action fields. Sociological Theory, 29, 1-26.

Fligstein, N., \& McAdam, D. (2012). A Theory of fields. New York, NY: Oxford University Press.

Gamson, W. (1975). The strategy of social protest. Homewood, IL: Dorsey Press.

Gamson, W., \& Modigliani, A. (1989). Media discourse and public opinion on nuclear power: a constructionist approach. American Journal of Sociology, 95, 1-37.

Givel, M. (2006). Punctuated equilibrium in limbo: The tobacco lobby and U.S. state policymaking from 1990 to 2003. Policy Studies Journal, 34, 405-418.

Goldstone, J. (2003). States, parties and social movements. Cambridge: Cambridge University Press.

Gottweiss, H. (2007). Rhetoric in policy making: Between logos, ethos, and pathos. In G. J. Miller \& K. Yang (Eds.), Handbook of public policy analysis: Theory, politics and methods (pp. 237-250). New York: Taylor and Francis.

Jann, W., \& Wegrich, K. (2006) Theories of the policy cycle. In G. J. Miller \& K. Yang (Eds.), Handbook of research methods in public administration (2nd ed., pp. 13-24). New York: Taylor \& Francis.

Johnson, E. (2008). Social movement size, organizational denisty and the making of federal law. Social Forces, 86, 1-28.

Johnson, E., Agnone, J., \& McCarthy, J. D. (2010). Movement organizations, synergistic tactics, and environmental public policy. Social Forces, 88, 2267-2292.

Jones, B. D., \& Baumgartner, F. R. (2004). Representation and agenda setting. Policy Studies Journal, 32, 1-24.

Jones, B. D., \& Baumgartner, F. R. (2005). The politics of attention. Chicago, IL: University of Chicago Press.

Jordan, A. G., \& Maloney, W. A. (1997). The protest business? Mobilizing campaign groups. Manchester: Manchester University Press.

Katzenstein, M. (1998). Stepsisters: Feminist movement activism in different institutional spaces. In D. S. Meyer \& S. Tarrow (Eds.), The social movement society: Contentious politics for a new century (pp. 195-216). Lanham, MD: Rowman \& Littlefield.

Katzmann, R. A. (1986). Institutional disability. Washington, DC: Brookings Institution.

King, B. G., Bentele, K. G., \& Soule, S. (2007). Protest and policymaking: Explaining fluctuation in congressional attention to rights issues, 1960-1986. Social Forces, 86, 137-163.

King, D. (1997). Turf wars. Chicago, IL: University of Chicago Press. 
Kingdon, J. W. (1994). Agendas, alternatives, and public policies. New York: Longman Press. Lawrence, T. B., \& Suddaby, R. (2006). Institutions and institutional work. In S. Clegg, C. Hardy, T. B. Lawrence \& W. R. Nord (Eds.), The SAGE handbook of organization studies (2nd ed., pp. 215-254). London: Sage.

Levitan, S. A., \& Taggart, R. (1976). The promise of greatness. Cambridge: Harvard University Press.

Longmore, P. L. (2003). Why I burned my books and other essays on disability. Philadelphia, PA: Temple University Press.

Lowi, T. J. (1964). American business, public policy, case-studies and political theory. World Politics, 16, 677-715.

McCarthy, J. D. (2005). Velcro triangles: Elite mobilization of local antidrug issue coalitions. In D. S. Meyer, V. Jenness \& H. Ingram (Eds.), Routing the opposition: Social movements, public policy, and democracy (pp. 87-115). Minneapolis, MN: University of Minnesota Press.

McCarthy, J. D., \& Zald, M. N. (1977). Resource mobilization and social movements: A partial theory. American Journal of Sociology, 82, 1212-1241.

Mettler, S. (2007). The transformed welfare state and the redistribution of political voice. In P. Pierson \& T. Skocpol (Eds.), The transformation of American politics: Activist government and the rise of conservatism ( $\mathrm{pp}$ 191-221). Princeton, NJ: Princeton University Press.

Meyer, D., \& Minkoff, D. (2004). Conceptualizing political opportunities. Social Forces, 82, $1457-1492$.

Miller, H. T., \& Demir, T. (2007a). Policy communities. In F. Fischer, G. J. Miller \& M. S. Sidney (Eds.), Handbook of public policy analysis: Theory, politics and methods (pp. 137-147). New York, NY:Taylor and Francis.

Miller, H. T., \& Demir, T. (2007b). Theory. In G. J. Miller \& K. Yang (Eds.), Handbook of research methods in public administration (2nd ed., pp. 13-24). New York: Taylor \& Francis.

O'Brien, R. (2001). Crippled Justice. Chicago, IL: Chicago University Press.

Olzak, S., \& Soule, S. A. (2009). Cross-cutting influences of environmental protest and legislation. Social Forces, 88, 201-225.

Patterson, J. (2000). America's struggle against poverty in the twentieth century. Cambridge, MA: Harvard University Press.

Pettinicchio, D. (2012). Institutional activism: Reconsidering the insider/outsider dichotomy. Sociology Compass, 6, 499-510.

Pierson, P. (2007). The rise and reconfiguration of activist government. In P. Pierson \& T. Skocpol (Eds.), The transformation of American politics: Activist government and the rise of conservatism (pp. 19-38). Princeton, NJ: Princeton University Press.

Polsby, N. W. (1984). Political innovation in America: The politics of policy initiation. New Haven, CT: Yale University Press.

Polsby, N. W. (2004). How Congress evolves: Social bases of institutional change. New York, NY: Oxford University Press.

Reichman, N., \& Canan, P. (2003). Ozone entrepreneurs and the building of global coalitions. In C. Humphrey (Ed.), Environment, energy, and society: Exemplary works (pp. 55-72). Belmont, CA: Wadsworth.

Riker, W. H. (1982). Liberalism against populism: A confrontation between the theory of democracy and the theory of social choice. Prospect Heights, IL: Waveland Press. 
Roa, H., Morrill, C., \& Zald, M. N. (2000). Power plays: How social movements and collective action create new organizational forms. Research in Organizational Behavior, 22, 239-282.

Roe, E. (1994). Narrative policy analysis: Theory and practice. Durham, NC: Duke University Press.

Rose, R., \& Davies, P. L. (1994). Inheritance in public policy. New Haven, CT: Yale University Press.

Santoro, W. A., \& McGuire, G. M. (1997). Social movement insiders: The impact of institutional activists on affirmative action and comparable worth policies. Social Problems, 44, 503-519.

Schattschneider, E. E. (1935). Politics, pressures and the tariff: A study of free private enterprise in pressure politics, as shown in the 1929-1930 revision of the tariff. New York, NY: Prentice-Hall.

Schneider, M., \& Teske, P. (1992). Toward a theory of the political entrepreneur: Evidence from local government. American Political Science Review, 86, 737-747.

Scotch, R. (2001). From good will to civil rights. Philadelphia, PA.Temple University Press.

Sheingate, A. D. (2006). Structure and opportunity: Committee jurisdiction and issue attention in Congress. American Journal of Political Science, 50, 844-859.

Skocpol, T. (2007). Government activism and the reorganization of American civic democracy. In P. Pierson \& T. Skocpol (Eds.), The transformation of American politics: Activist government and the rise of conservatism (pp. 39-67). Princeton, NJ: Princeton University Press.

Skrentny, J. (2002). The minority rights revolution. Cambridge: Harvard University Press.

Smith, S., \& Deering C. (1990). Committees in congress (2nd ed.). Washington, DC: Congressional Quarterly.

Stearns, L. B., \& Almeida, P. D. (2004). The formation of state actor-social movement coalitions and favorable policy outcomes. Social Problems, 51, 478-504.

Stone, D. (2002). Policy paradox. The art of political decision making (rev. ed.). New York, NY: W.W. Norton.

Sulkin, T. (2005). Issue politics in Congress. New York, NY: Cambridge University Press.

Thelan, K. (1999). Historical institutionalism in comparative politics. American Review of Political Science, 2, 369-404.

Tilly, C. (1978). From mobilization to revolution. New York, NY: Random House.

True, J. L., \& Utter, G. H. (2002). Saying "Yes," "No," and "Load Me Up" to guns in America. The American Review of Public Administration, 32, 216-241.

Van Eeten, M. J. G. (2007). Narrative policy analysis. In G. J. Miller \& K. Yang (Eds.), Handbook of research methods in public administration (2nd ed., pp. 251-269). New York: Taylor \& Francis.

Wawro, G. (2001). Legislative entrepreneurship in the U.S. House of Representatives. Ann Arbor, MI: University of Michigan Press.

Weingast, B. R. (2005). Caught in the middle: The president, Congress, and the politicalbureaucratic system. In J. D. Aberbach \& M. A. Peterson (Eds.), The executive branch (pp. 312-343). New York, NY: Oxford University Press. 